\title{
Revised distribution of an Alaskan endemic, the Alaska Hare (Lepus othus), with implications for taxonomy, biogeography, and climate change
}

\author{
Michelle M. Cason, Andrew P. Baltensperger, Travis L. Booms, \\ John J. Burns, and Link E. Olson
}

\begin{abstract}
The Alaska Hare (Lepus othus Merriam 1900) is the largest lagomorph in North America but remains one of the most poorly studied terrestrial mammals on the continent. Its current distribution is restricted to western Alaska south of the Brooks Range, but historical accounts from north of the Brooks Range (the North Slope) have led to confusion over its past, present, and predicted future distributions. To determine if L. othus occurs or historically occurred on the North Slope, we surveyed museum collections, vetted observational accounts, and produced a spatial distribution model based on the resulting georeferenced records. We located a historic specimen long presumed lost that suggests the occurrence of L. othus on the North Slope as recently as the late 1800s. We also uncovered evidence of L. othus and (or) Mountain Hare (Lepus timidus Linnaeus 1758) on several islands in the Bering Sea, raising the possibility of recurring gene flow between these closely related species across seasonal ice connecting Asia and North America. While our results paint a more complete picture of the current distribution of L. othus, persistent uncertainties surrounding its taxonomic status and potential northward range shift onto lands reserved for oil and gas development call for additional study.

Key words: Alaska Hare, Arctic Hare, Lepus othus, Mountain Hare, North Slope.
\end{abstract}

Résumé : Le lièvre d'Alaska (Lepus othus Merriam 1900) est le plus grand lagomorphe en Amérique du Nord mais il demeure un des mammifères terrestres du continent qui n'a aiment pas fait l'objet d'études. Sa distribution actuelle est restreinte à l'ouest de l'Alaska au sud de la chaîne de Brooks, mais les récits historiques provenant du nord de la chaîne de Brooks (le versant nord de l'Alaska) ont créé une certaine confusion au sujet de ses distributions passée, présente et prédite pour le futur. Dans le but de déterminer si L. othus est présent ou était présent historiquement sur le versant nord de l'Alaska, nous avons étudié les collections dans les musées, vérifié les récits d'observation, et créé un modèle de la distribution spatiale fondé sur les mentions géoréférencées. Nous avons repéré un spécimen historique longtemps présumé perdu qui suggère la présence de $L$. othus sur le versant nord de l'Alaska aussi récemment que la fin du dix-neuvième siècle. Nous avons aussi trouvé la preuve de la présence de L. othus et (ou) du lièvre variable (Lepus timidus Linnaeus 1758) sur plusieurs îles dans la mer de Béring, ce qui soulève la possibilité du flux de gènes récurrent entre ces espèces étroitement liées entre la glace saisonnière reliant l'Asie et l'Amérique du Nord. Tandis que nos résultats brossent un tableau complet de la distribution

Received 8 May 2015. Accepted 8 March 2016.

M.M. Cason. Department of Mammalogy, University of Alaska Museum, 907 Yukon Drive, Fairbanks, AK 99775, USA; Department of Biology and Wildlife, University of Alaska Fairbanks, 982 N. Koyukuk Drive, Fairbanks, AK 99775, USA. A.P. Baltensperger. Gates of the Arctic National Park, National Park Service, 4175 Geist Road, Fairbanks, AK 99709, USA. T.L. Booms. Alaska Department of Fish and Game, Wildlife Diversity Program, 1300 Cllege Road, Fairbanks, AK 99701, USA. J.J. Burns and L.E. Olson. Department of Mammalogy, University of Alaska Museum, 907 Yukon Drive, Fairbanks, AK 99775, USA.

Correspondence: Michelle Cason (email: mmcason@alaska.edu).

This article is open access. This work is licensed under a Creative Commons Attribution 4.0 International License (CC BY 4.0). http://creativecommons.org/licenses/by/4.0/deed.en_GB. 
actuelle de L. othus, des études supplémentaires seraient nécessaires en raison des incertitudes persistantes entourant son statut taxonomique et de son déplacement potentiel vers le nord sur des terres réservées à la mise en valeur du pétrole et du gaz.

Mots-clés : lièvre d’Alaska, lièvre arctique, Lepus othus, lièvre variable, versant nord de l'Alaska.

\section{Introduction}

The Alaska Hare (Lepus othus Merriam 1900) is the largest hare in North America (Feldhammer et al. 2003) and is the only terrestrial vertebrate with a distribution restricted to the vast roadless, unforested region of western Alaska south of the Brooks Range (MacDonald and Cook 2009). Despite these distinctions, little is known about its natural history, ecology, population dynamics, or distribution. Far more research has been conducted on the two other species in the northern hare complex, the Arctic Hare (Lepus arcticus Ross 1819) from northern Canada and the Mountain Hare (Lepus timidus Linnaeus 1758) from northern Eurasia, each of which occupies a much larger current range than does L. othus. For the purpose of disambiguation, we follow MacDonald and Cook (2009) in referring to L. othus as the "Alaska" and not "Alaskan" Hare, since there are two hare species native to Alaska and therefore two "Alaskan hares." Similarly, we capitalize formal common names.

The unique distribution of $L$. othus has been the source of confusion for over a century (Fig. 1). Until now, there has been no verifiable evidence of the occurrence of L. othus on the tundra north of the Brooks Range (the North Slope hereafter), but historical anecdotal accounts dating from the late 19th through the mid-20th century (Bee and Hall 1956) continue to influence published range maps (e.g., Klein 1995; Wilson and Ruff 1999; Feldhammer et al. 2003) (Fig. 1). The only specimen purportedly collected from the North Slope was acquired by the 1898 Arctic expedition led by Edward Avery Mcllhenny, who obtained a large hare from near Point Barrow (Stone 1900). The fate of this specimen has long been unknown and subsequent researchers have been unable to confirm its identification (Anderson 1978) and have even reported it lost (Bee and Hall 1956). As a result, no North Slope records or specimens were included in MacDonald and Cook's (2009) distribution map of L. othus. Reported measurements (Stone 1900) indicated that the skeleton was too large to be Snowshoe Hare (Lepus americanus Erxleben 1777), leading Anderson (1978) to provisionally identify the specimen sight unseen as L. othus. Out of $318 \mathrm{~L}$. othus specimens available for study, it remains the only purported voucher from anywhere north of the Brooks Range.

The most comprehensive study of the natural history and systematics of L. othus (Anderson 1974) included a map of all known collection localities of the 189 then-known specimens. The range map encompassed the west coast of Alaska, from the southern Alaska Peninsula to the Kotzebue Sound region, but did not include the North Slope (Anderson 1978). By 1974, there had been no additional sightings of L. othus on the North Slope, "despite increased biological investigations associated with recent oil and gas activities" (Anderson 1978, p. 73). Industrial development on the North Slope has increased since the 1970s, along with the biological research required to assess environmental impacts. To date, there have been no sightings reported from the North Slope since 1950 and no large-bodied hare specimens collected since 1898.

Because no voucher specimens could be located, the historical occurrence of $L$. othus north of the Brooks Range has been uncertain. Forest cover is expected to increase and low shrub habitat is expected to decrease in northwest Alaska over the next century (Jorgenson et al. 2015). Lepus othus is projected to lose $5 \%$ of its habitat in the national public lands of the region (Bering Land Bridge National Preserve, Cape Krusenstern National Monument, Gates of the Arctic National Park and Preserve, Kobuk Valley National Park, Noatak National Preserve, and Selawik National Wildlife Refuge) by the year 2100 (Marcot et al. 2015). However, other 
Fig. 1. Previously published distribution maps for Lepus othus. (A) North Slope distribution of L. othus from Bee and Hall (1956). All localities except number 2 (the locality estimate for the Mcllhenny specimen) are based on secondor third-hand anecdotal accounts made to the authors. (B) Distribution from Best and Henry (1994), reproducing the distribution from Hall (1981). (C) Distribution from Anderson (1978) with specimen collection localities and distributions mapped by Howell (1936), Bee and Hall (1956), Hall and Kelson (1959), Rausch (1963), and Anderson (1974). (D) Distribution from Alaska Gap Analysis Project (http://aknhp.uaa.alaska.edu/zoology/akgap/).

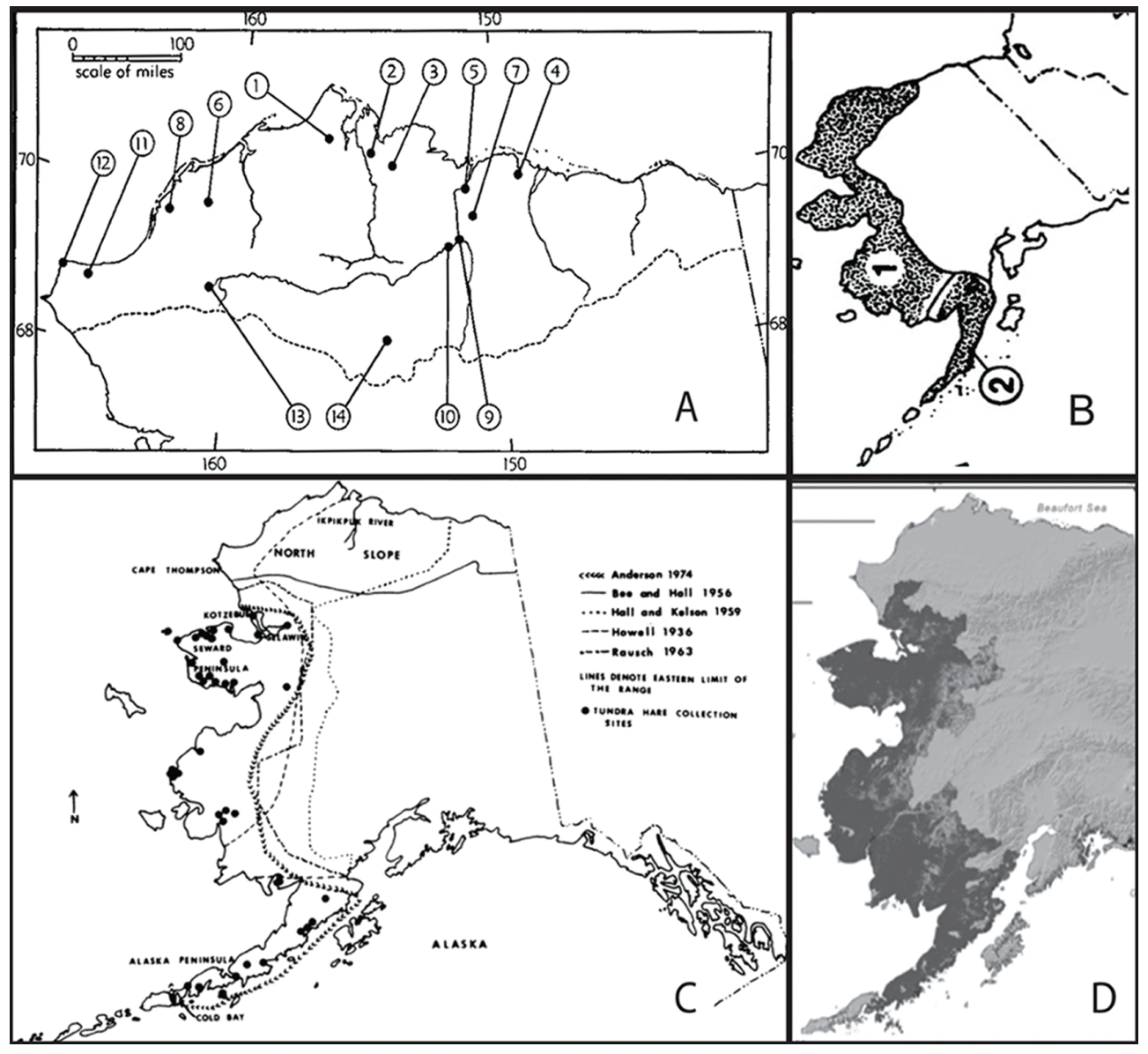

species distribution models (Leach et al. 2015) predict an $80 \%$ increase in the bioclimatic envelope of $L$. othus between the beginning of the 20th and end of the 21st centuries, along with a $3 \%$ mean latitudinal increase.

Lepus othus feeds on willow (Salix spp.), crowberry (Empetrum nigrum), and various other ericaceous plants, grasses, sedges, and lichens (Anderson 1974). It is preyed on by both Red Fox (Vulpes vulpes) and Arctic Fox (V. lagopus), and Golden Eagles (Aquila chrysaetos) (Anderson 1974). Lepus othus remains (University of Alaska Museum (UAM) Mammal Collection specimen 113979) have also been found in Gyrfalcon (Falco rusticolus) nests. Other likely predators include Snowy Owl (Bubo scandiacus), Gray Wolf (Canis lupus), and Rough-legged Hawk (Buteo lagopus) (Anderson 1974).

Potential ecological interactions between L. othus and the only other native leporid in Alaska, the Snowshoe Hare (L. americamus), has been suggested but not directly studied (Klein 1995). The two species are sympatric throughout much of western Alaska (MacDonald 
Fig. 2. IUCN range maps (Murray and Smith 2008a,b,c) of Lepus othus (black, western Alaska), Lepus arcticus (black, northern Canada), and Lepus americanus (light gray). Range overlap is shown in dark gray. The range of $L$. arcticus extends north and northeast off panel.

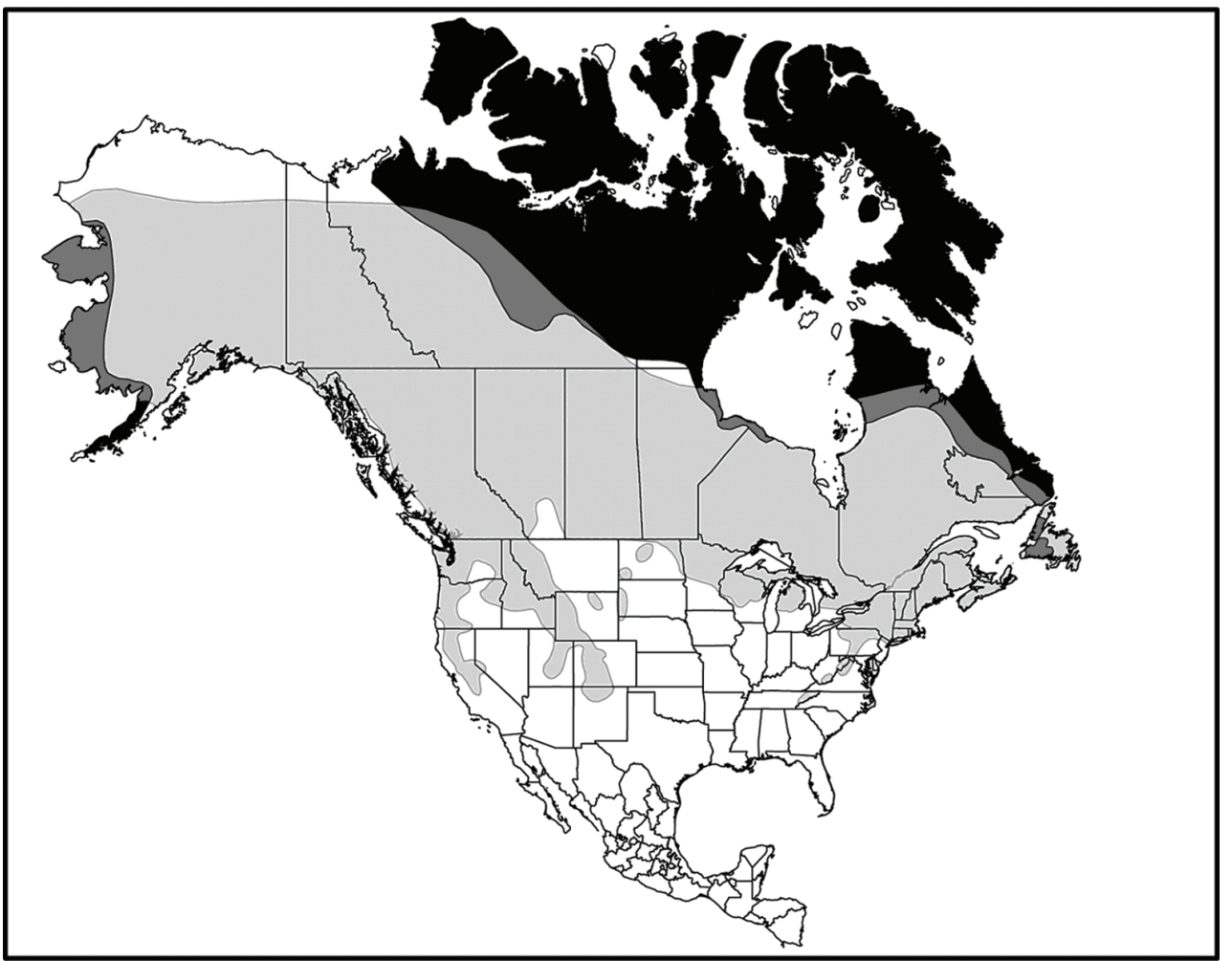

and Cook 2009) (Fig. 2) and are frequently confused due to their similar pelage. Lepus americanus occurs throughout most of mainland Alaska except the western half of the Seward Peninsula and all but the easternmost terminus of the Alaska Peninsula (ADFG; MacDonald and Cook 2009) while L. othus is restricted to coastal western Alaskan (MacDonald and Cook 2009).

In light of the inordinately rapid pace of environmental change in Alaska's Arctic and coastal tundra regions, the unique and restricted yet poorly understood range of L. othus, and the four decades that have elapsed since the distribution of this Alaskan endemic was last rigorously evaluated, we conducted an extensive review of the present distribution of L. othus. We hypothesized that there is no evidence to include the North Slope in the present distribution of L. othus and that the historical anecdotal accounts from the North Slope could not be corroborated by voucher specimens. Our review was based on museum specimens, photographs, literature records, and credible observations. We also compared the known distribution based on these data to a spatial distribution model for L. othus.

\section{Materials and methods}

We surveyed 39 North American and Canadian museums (Appendix Table 1) for L. othus specimens through online database searches, contact with curators and collection managers, and (or) personal visits. All known L. othus specimens are listed in Supplementary Material Table $1^{1}$. Museums surveyed but not listed in Table S1 had no L. othus specimens.

${ }^{1}$ Supplementary material is available with the article through the journal Web site at http://nrcresearchpress.com/doi/suppl/10.1139/ as-2015-0019. 
We confirmed identifications by skull size and (or) winter pelage coloration (see below) through personal inspection or photographs from curators and collection managers. Where neither was possible, we considered the familiarity of the collector or identifier with both $L$. othus and the only other hare known to occur in sympatry and with which it is occasionally confused, L. americanus. Lepus othus in its winter pelage is easily identified by distinctive black-tipped ears and fur that is white to the roots. Winter pelage of L. americanus is white tipped with dark roots and does not include black fur on the inner tips of the pinnae (although black may be present along the edges).

In addition to traditional voucher specimens, we included accounts of L. othus catalogued and curated as observations in the Mammal Collection of the UAM. We evaluated these records on a case-by-case basis prior to cataloguing, and they generally included photographs or video to corroborate identification. In some cases, observer expertise alone was considered sufficient following interviews by museum staff. Catalog numbers for UAM observations are denoted with the prefix "UAMObs."

Lepus othus specimens with collection locality descriptions but without geographic coordinates were assigned coordinates (WGS 84 datum) and error radii with the georeferencing platform GEOLocate (Rios and Bart 2014). Misspelled place names were corrected according to the Dictionary of Alaska Place Names (Orth 1971). Locality descriptions that were not recognized by GEOLocate were manually assigned coordinates and error radii with Google Earth Pro v. 7.0.3.8542. Error radii were determined according to BioGeoMancer standards for estimating error from locality descriptions (Chapman and Wieczorek 2006). Locations with error radii exceeding $200 \mathrm{~km}$ were georeferenced but not included in Fig. 3. Place names or descriptions that could not be located were not assigned coordinates and are not shown in Fig. 3 but are included in Table S1. We georeferenced all specimens collected between 1877 (the earliest known modern L. othus specimen) and 2014. We did not examine paleontological or zooarchaeological material, which tends to be fragmentary and identified in the literature and (or) on collections databases to genus level only.

We used RandomForests (Salford Systems, Inc., San Diego, California; www.salford-systems.com) to create a spatial distribution model for L. othus. The resulting model accounts for the confounding and nonlinear relationships among variables (Breiman 1996; Cutler et al. 2007). Collection localities (Table S1) with accuracy within $100 \mathrm{~km}$ were used as presence points for the spatial distribution model. Presence locations and 500 randomly distributed pseudo-absence points for L. othus were attributed with 28 environmental predictor layers (Table 1) using the extract values to multipoint tool in ArcGIS 10.3.1 (ESRI, Inc., Redlands, California) and used as training data to develop the model in RandomForests. The model was grown to 1000 trees, considered eight predictors at each node, and used all other software default settings. Aspatial performance was cross-validated internally in RandomForest using an "out-of-bag" set of training points (Breiman 1996). The discrimination capacity of each model was assessed using resultant sensitivity and specificity of the out-of-the bag data set and the area under the curve (AUC) based on the receiver-operating characteristic (ROC). The model was applied in ArcGIS 10.3 .1 to a grid of points distributed at $1 \mathrm{~km}$ intervals across Alaska that were also attributed with the same environmental predictors. Model outputs generated relative indices of occurrence (RIO) for each point, which is a ranking of pixels from 0 to 1 representing the likelihood of belonging to the "presence" class. A balanced threshold of 0.55 was used to differentiate between presences and absences for all models. For continuous visualization between points, predicted RIO values were rasterized using the Inverse Distance Weighting (IDW) tool using a 1-km resolution and clipped to the state coastline. RandomForests was also used to rank the relative importance of the environmental variables in the model. 
Fig. 3. Collection localities of all catalogued Lepus othus museum specimens and observations, other localities discussed in text, and the distribution boundary from Anderson (1974).

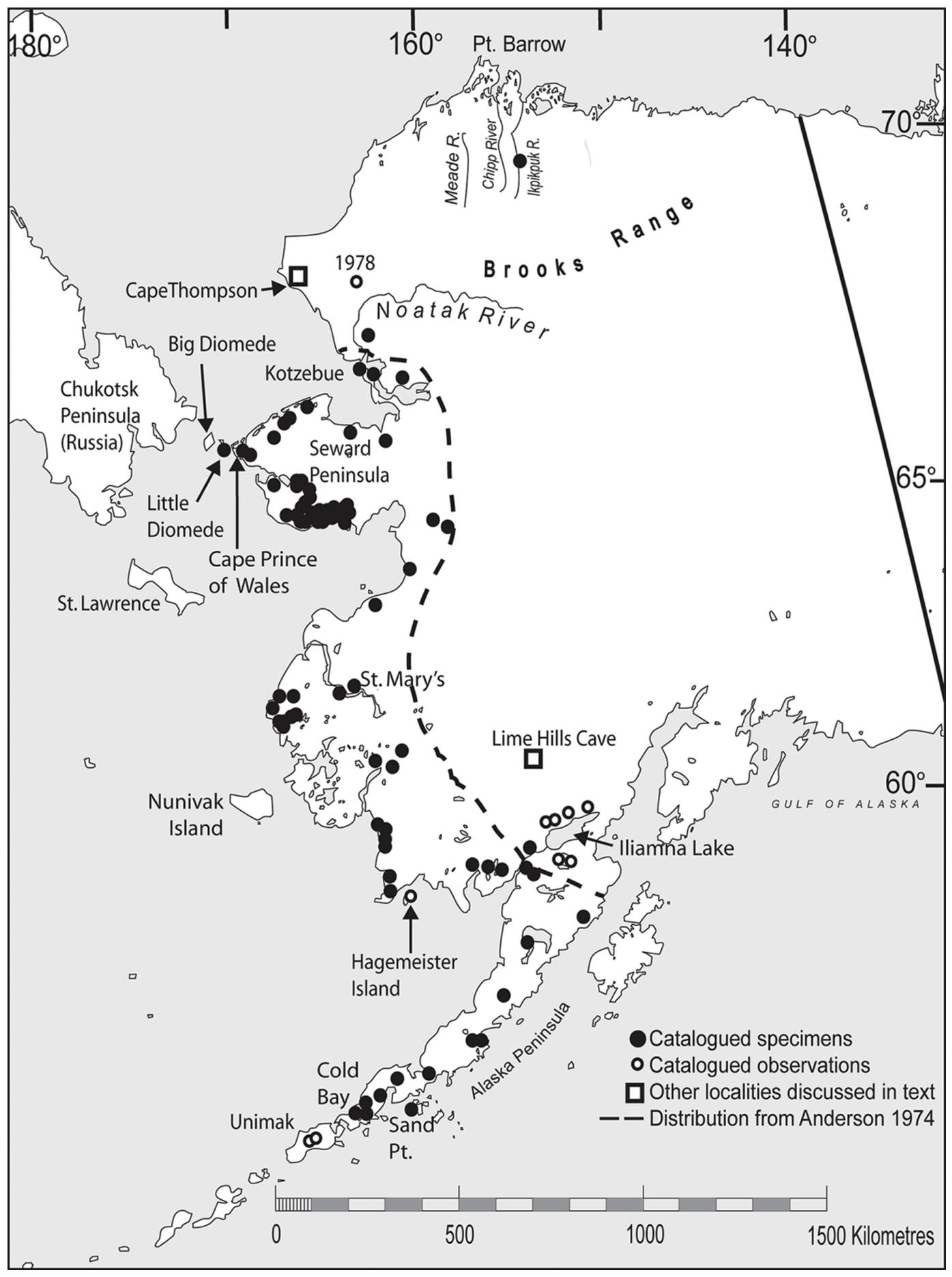


Table 1. Environmental variables and their relative importance to the spatial distribution model.

\begin{tabular}{lc}
\hline Variable & Relative score \\
\hline Distance to March sea ice & 100.00 \\
Distance to coastline & 68.22 \\
Cliome & 47.74 \\
Geology & 36.26 \\
Elevation & 28.30 \\
Mean temperature for September/October/November & 21.91 \\
Mean \% of days where precipitation fell as snow in September/October/November & 10.21 \\
Mean first day of freeze & 8.36 \\
Mean \% of days where precipitation fell as snow in March/April/May & 7.27 \\
Mean temperature for March/April/May & 5.47 \\
Mean \% of days where precipitation fell as snow in December/January/February & 5.42 \\
Mean ground temperature & 5.03 \\
Mean temperature for December/January/February & 4.49 \\
Distance to September sea ice & 3.85 \\
Mean first day of thaw & 3.84 \\
Distance to lakes & 2.51 \\
Mean number of grow days & 2.02 \\
Mean temperature for June/July/August & 1.98 \\
Mean \% of days where precipitation fell as snow in June/July/August & 1.57 \\
Mean precipitation for September/October/November & 1.22 \\
Mean precipitation for March/April/May & 1.11 \\
Mean precipitation for June/July/August & 0.96 \\
Mean precipitation for December/January/February & 0.76 \\
Mean active layer thickness & 0.74 \\
Distance to streams & 0.63 \\
Aspect & 0.45 \\
Distance to wetland vegetation & 0.41 \\
Slope & 0.23 \\
\hline
\end{tabular}

\section{Results}

We located 318 specimens of L. othus from 12 museum and other collections and were able to georeference 305 from their locality descriptions (Fig. 3; Table S1). Many were already associated with geographic coordinates available from the host museum. These localities spanned much of Alaska's west coast but the majority (175) of specimens were collected from the Seward Peninsula (Fig. 3). The current northernmost range limit was extended approximately $50 \mathrm{~km}$ north after collection of the first L. othus voucher (UAM 120460) from Noatak National Preserve in April 2014. There was also a credible sighting (UAMObs 213) of an L. othus individual in 1978 in the western Brooks Range approximately $150 \mathrm{~km}$ northeast of where UAM 120460 was collected. The southernmost specimens were collected in Cold Bay, approximately $50 \mathrm{~km}$ from the terminus of the Alaska Peninsula, as recently as 1993 (UAM 42143). We personally confirmed the species identification of the northern- and southernmost specimens, both of which are housed at UAM. Most specimens were collected close to Alaska's western coastline. The inland-most specimens were collected near St. Mary's, less than $150 \mathrm{~km}$ from the coast. Several reliable observations (UAMObs 219-225) originated near Iliamna Lake, which is farther east than almost all specimen collection localities but less than $100 \mathrm{~km}$ inland from the Gulf of Alaska. 
We located the "lost" Mcllhenny specimen (CMN 31930), a skull and postcranial skeleton collected from near Barrow, in the Mammal Collection at the Canadian Museum of Nature. Data on the specimen tag confirm that it is the same specimen listed in the expedition's report (Stone 1900). We borrowed the specimen and verified that the craniodental measurements were within the range of the L. othus specimens measured by Anderson (1974) and exceeded the maximum basilar skull length of L. americanus $(67 \mathrm{~mm})$ reported by Hall (1981). Visual comparisons also confirmed that it is not L. americanus.

Two new credible observations of L. othus on Unimak Island (the easternmost of the Aleutian Islands) in 2013 and 2014 (UAMObs 182, UAMObs 192) were reported, and a photograph of an L. othus individual on Hagemeister Island (UAMObs 181) was taken by a camera trap at a walrus haulout site in 2013. Both Hagemeister and Unimak are close to mainland Alaska $(<5$ and $<1 \mathrm{~km}$, respectively) and are sometimes connected to the mainland by sea ice in late winter and early spring. Additionally, one or more very large hares fitting the description of either L. timidus or L. othus were reported from St. Lawrence Island (Fig. 3) in the winter of 2012 (G. Sheffield, personal communication) and are the first known sighting of a hare on that island. Prior to this study, Alaska Hares were not known from any of these islands.

Russia's Chukotsk Peninsula and Alaska's Seward Peninsula are $80 \mathrm{~km}$ apart. Midway between them lie the two Diomede Islands. Large-bodied hares currently identified as $L$. othus have been collected from Little Diomede Island in 1936 (USNM 260900) and more recently in 2014 (UAM 120797, UAM 122839) but have only been sporadically reported from the island. During winter 2013-2014, several hares were observed on Little Diomede (including the two UAM specimens). UAM 120797 was pregnant with seven near-term embryos when shot by subsistence hunters in June 2014. Little Diomede lies $37 \mathrm{~km}$ west of Alaska's Seward Peninsula and less than 4 km east of Russia's Big Diomede Island, which in turn is only $35 \mathrm{~km}$ east of the Chukotsk Peninsula; all are interconnected by sea ice for up to 6 months out of the year (NSIDC 2013). In the 1960s, bush plane pilot Bill Munz reportedly saw a "huge" aggregation of large-bodied hares moving east on the sea ice between Little Diomede Island and Cape Prince of Wales (J. Jacobson, personal communication) (Fig. 3), which is on the western tip of the Seward Peninsula. Whether the hares collected from Little Diomede in 2014 represent L. othus from Alaska or L. timidus from Russia remains unclear, as does the present occurrence of hares on Big Diomede. However, residents on Little Diomede recounted the regular occurrence of hares on Big Diomede and sporadic dispersal to Little Diomede (personal communication to J.J.B.) in the 1960s.

Curiously, no specimens or observations of hares are known from Nunivak Island (Fig. 3), the second-largest island in the Bering Sea and only $30 \mathrm{~km}$ from mainland western Alaska, to which it is seasonally connected by sea ice. Residents and hunting guides on Nunivak report that hares do not occur on the island (W. Don, personal communication). Our spatial distribution model (Fig. 4) predicts their likely presence on Nunivak, but the reason(s) for the apparent absence of L. othus there remains unknown.

Murie (1959) noted the absence of L. othus on Unimak Island (Fig. 3) after his faunal survey of the Alaska Peninsula and Aleutian Islands in the 1930s. MacDonald and Cook (2009) reported no island records from southwest Alaska, aside from a failed introduction on Chirikof Island (Fig. 3). However, one specimen (USNM 203278; identification confirmed by L.E.O.) is listed as having been collected from Sand Point (Fig. 3), on Popov Island, in 1913. Popov Island is not surrounded by sea ice in the winter, and ocean currents in the Unga Strait separating the island from the southern coast of the Alaska Peninsula are strong and constant. The village of Sand Point was, like Barrow, a trading center for many years; it is possible that the specimen may have been collected on the mainland and brought to Sand Point. Alaska Hares are not known to occur on Popov Island today, and Snowshoe Hares introduced to the island in 1955 are reported to be abundant (MacDonald and Cook 2009; 
Fig. 4. Spatial distribution model of the present distribution of Lepus othus. Red circles mark presences (georeferenced collection localities). Blue circles indicate pseudoabsences. Relative indices of occurrence (RIO) values greater than 0.55 indicate regions of likely presence, and values less than 0.55 indicate regions of likely absence.

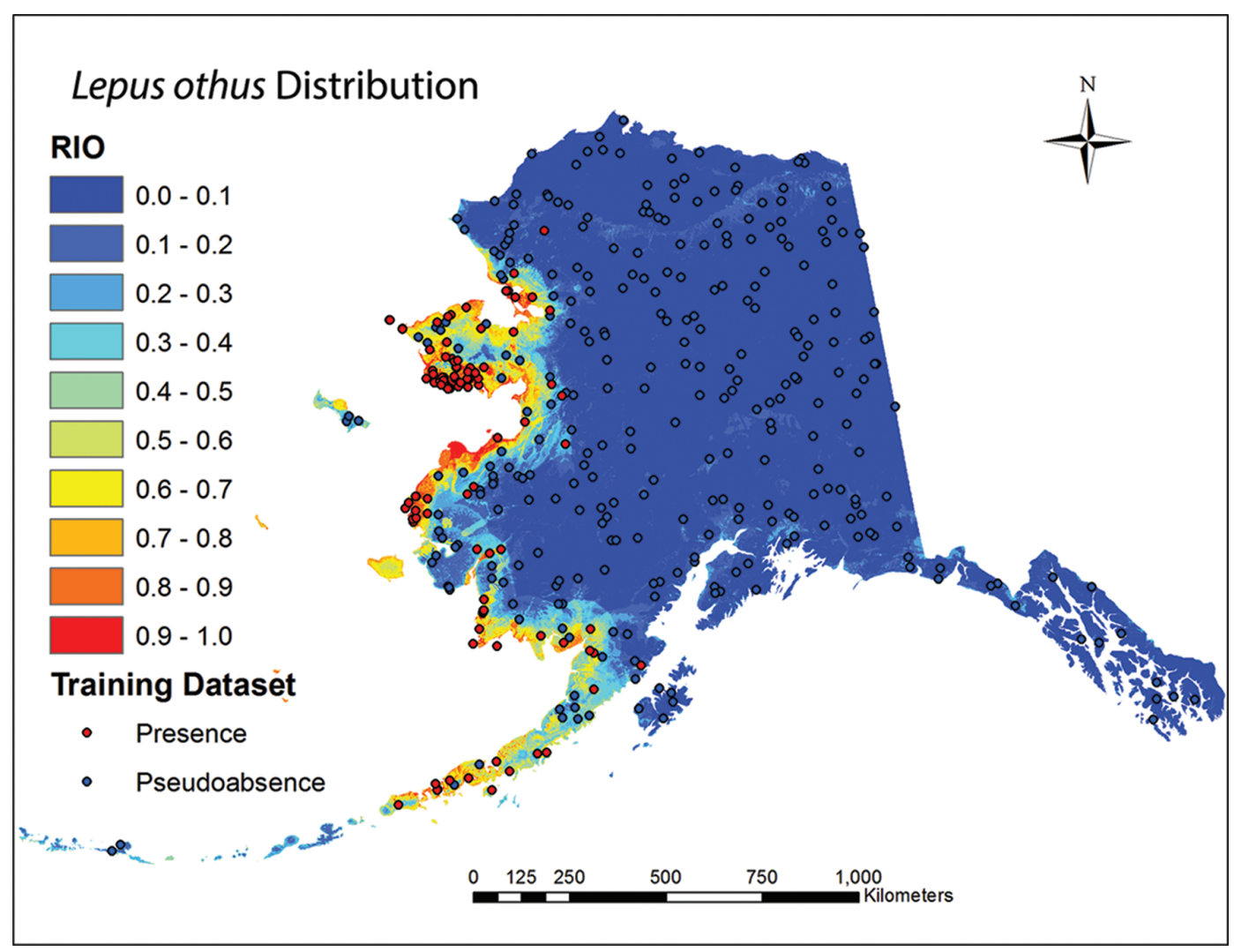

D. Watts, personal communication). The two observations of L. othus on Unimak (UAMObs 182 and UAMObs 192) and a photograph of L. othus on Hagemeister (UAMObs 181) are additional evidence of L. othus on islands in southwestern Alaska.

The spatial distribution model closely matched the known distribution based on specimen and observation localities (Fig. 4). The ROC value was 0.98 , the balanced error rate was 0.06 , the sensitivity was $94.24 \%$, and the specificity was $94.00 \%$. Distance to March sea ice and the distance to the coastline were the most important variables in the model (Table 1). The northernmost specimen collection locality is in an area of likely L. othus presence, as predicted by the spatial distribution model. However, the location of the northernmost credible observation is in the midst of the Brooks Range, where the model predicts the absence of L. othus. The model did predict the presence of L. othus on St. Lawrence Island, despite the pseudo-absence localities used in the data set. We did not include the observation of a large-bodied hare on St. Lawrence Island as a presence point because we received it third-hand and it is not considered a catalogued observation.

\section{Discussion}

Based on the collection locality of UAM 120460, we consider the current northernmost known range limit of L. othus to be approximately $50 \mathrm{~km}$ northeast of Kotzebue. Prior to the acquisition of this specimen and the "rediscovery" of CMN 31930 from the North Slope, 
the northernmost L. othus voucher was collected in the Kotzebue area (UAM 4132). In May 1978, a L. othus individual was sighted $190 \mathrm{~km}$ northeast of Kotzebue, well into the Brooks Range (UAMObs 213), by a professional hunting guide very familiar with both $L$. othus and L. americanus. The spatial distribution model expects the northernmost range extent of $L$. othus to be near Kivalina, which is about $105 \mathrm{~km}$ northwest of the northernmost collection locality. We consider the range of L. othus to include the area in which the species is consistently found while acknowledging what are likely dynamic boundaries, particularly along the northern limit of its core range. Therefore, we do not consider the current distribution of L. othus to include the North Slope. The absence of L. othus on the vast tundra landscape of Alaska's North Slope remains vexingly inexplicable and warrants thorough exploration.

The Mcllhenny expedition reported the "Ikpikpun river" as the collection location of the North Slope specimen (Stone 1900, p. 30). However, the donor of the specimen, Charles Brower, reported having the hare brought to him in 1897 from "inland on the Chipp River" and later giving "the whole animal to E. A. Mcllhenny, who sent it out with his collection" (Howell 1936, p. 334). Although we could not locate an "Ikpikpun River" on contemporary maps of Alaska, the Ikpikpuk River is about $50 \mathrm{~km}$ east of the Chipp River and lies approximately $100 \mathrm{~km}$ southeast of Point Barrow. The Smithsonian Contributions to Anthropology described the location of the Ikpikpun River as east of Point Barrow (Stanford 1976) and Murdoch (1892) described it as about 40 miles east of the Meade River, which is the approximate location of the Ikpikpuk River. We therefore conclude that the specimens reported by both Brower and the expedition (stationed in Point Barrow between August 1897-1898) are one and the same.

Long-distance dispersal $(200 \mathrm{~km})$ has been documented in L. timidus (Angerbjörn and Flux 1995) and it is likely that L. othus has occasionally dispersed well outside the species' current core range. According to both the expedition report (Stone 1900) and Brower (Howell 1936, p. 334), CMN 31930 was collected on the North Slope and not transported there by hunters or traders (although not an Alaska Native, Brower spoke fluent Iñupiaq). It is possible that Brower's understanding of the collection locality was incorrect and the hare was killed elsewhere and brought to the North Slope, perhaps via a series of trades. However, the fact that external measurements were recorded (Stone 1900) indicates that the specimen was an intact carcass available to either the expedition or Brower. An entire L. othus brought to the Point Barrow region from the closest point of its current distribution (about $500 \mathrm{~km}$ away) seems cumbersome but possible, especially with winter sled dog travel when the hare could be kept frozen and long-distance travel was common (Burch 1988). If, however, it was collected at its reported location, it may represent an anomalous disperser from northwest Alaska that made its way to the North Slope along the coast.

In their seminal but contentious book, Bee and Hall (1956) included the North Slope in the range of L. othus (Fig. 1). However, they did not examine any specimens to vouch for a North Slope occurrence, and others (Buckley and Scott 1957) criticized the authors' limited field research and dependence on personal communication. The Mcllhenny specimen from near Point Barrow (which Bee and Hall proclaimed lost or misplaced) was the only evidence to corroborate any of Bee and Hall's North Slope records; the other 13 localities represented second- or third-hand accounts. Our exhaustive search did not locate any specimens to confirm Bee and Hall's other locality records. The Mcllhenny specimen provides the only verifiable evidence that at least one Alaska Hare occurred on Alaska's North Slope in the late 19th century.

Questionable field identifications may have contributed to anecdotal reports of L. othus on the North Slope. John Murdoch, an early naturalist and source for Bee and Hall (1956), reported that Alaska Natives in Point Barrow were unfamiliar with L. othus but that the "Nunatangmeau" Eskimos brought hare skins there for trade. He considered these skins 
evidence of "polar hares" occurring "somewhere in the Colville Region" (Murdoch 1885:103). However, the dark roots of the fur on these skins, which are catalogued (USNM E89915-0 and USNM E89915-1) in the Anthropology Collection of the United States National Museum of Natural History, confirm that they are L. americanus. It is likely that the authors of many early reports may not have been able to differentiate between L. othus and L. americanus or between traveling Alaska Native groups, which casts further doubt on the validity of these records.

Another possible L. othus specimen from the North Slope resides at the California Academy of Sciences (CAS 23818). The specimen is a discolored pelt without head or feet but with pelage resembling that of L. othus. According to the limited associated data, it was purchased from a trader in Barrow, Alaska, in the early 1960s. The skin tag identifies the specimen as an "Arctic Hare Lepus arcticus," a close relative of L. othus that ranges across much of northern Canada but does not occur in Alaska. However, the term "Arctic hare" to this day is commonly, if erroneously, used to refer to L. othus. If the animal was collected in the Barrow area, it was likely L. othus. The hide was tanned, a process that significantly damages DNA, and we cannot conclusively identify the specimen as L. americanus, L. othus, or L. arcticus on visual inspection. In light of the uncertain provenance and identification, we do not consider it to be a credible voucher.

Zooarchaeological evidence of L. othus has been reported from Cape Thompson (Fig 3) (Pruitt 1966), where bones and teeth identified as L. othus were discovered in the remains of 150- to 200-year-old Eskimo dwellings. However, it is unclear if L. othus actually occurred at Cape Thompson or was hunted elsewhere and brought there. Other archaeological and zooarchaeological remains from Alaska include numerous specimens identified as "Lepus sp." or as "Lepus othus or Lepus americanus" (AMNH:FAM:99926; Yesner 2001). Identification of these remains would provide valuable insight into the past distribution of both species.

No other extant mammal is restricted to coastal western and southwestern Alaska without also being found on the North Slope (MacDonald and Cook 2009), and it is unclear why the current distribution of L. othus is apparently limited to south of the Brooks Range. The closely related and morphologically indistinguishable L. arcticus is found much farther north in Canada (Fig. 2) in more extreme environments than are found on Alaska's North Slope. The presumed expansion of L. americanus to the North Slope indicates that the mountains of the Brooks Range are not a significant barrier to hares. The 1978 sighting of L. othus well within the western Brooks Range (UAMObs 213) may indicate the occurrence of occasional long-distance dispersers north of the current range extent or stepwise dispersal over multiple generations. Although there is no apparent biogeographic barrier, the western distribution of L. arcticus likewise appears to end abruptly in the Northwest Territories, Canada, and does not extend to Alaska's North Slope. Waltari et al. (2004) concluded that the Mackenzie River, in northwest Canada, is a boundary between the two species, which may have expanded from two different glacial refugia, as has been hypothesized for small mammals such as the Collared Lemming, Dicrostonyx groenlandicus (Fedorov and Stenseth 2002). Porsild (1945) reported unspecified evidence that he attributed to L. arcticus in the Richardson Mountains west of the MacKenzie River in July 1933 and on gravel ridges in the foothills between the Mackenzie Delta and the Alaska border. However, it remains unclear why northern hares, medium-sized mammals that have been recorded dispersing over great distances (Angerbjörn and Flux 1995), do not occur on the tundra north of the Brooks Range. The spatial distribution model does not predict the presence of $L$. othus on the North Slope, which may be unfavorable to northern hares for as-yet unknown reasons, such as snow pack and terrain.

It is unclear if the apparent northward expansion of L. americanus has affected the geographic range of L. othus. There is little mention of L. americanus north of the Brooks Range 
before the 1990s (Klein 1995; MacDonald and Cook 2009) except along waterways with willows "at times of high population" (Manville and Young 1965, p. 16). Tape et al. (2015) calculated that shrub height in northern Alaska reached the threshold required by L. americanus between 1964 and 1989.

Unlike L. arcticus and L. othus, L. timidus is found in boreal forest in addition to alpine and tundra habitat, possibly because L. americanus, which thrives in the boreal forests of North America, does not occur in Eurasia. Lepus arcticus can survive at low densities in shrub or partially forested habitat in the absence of mammalian predators and competition from L. americanus (Small and Keith 1992). Lepus othus may be able to similarly persist in forested habitat. In Newfoundland, L. americanus has been shown to be more resilient than L. arcticus to predation by Red Foxes (Small and Keith 1992), possibly by favoring understory cover. Lepus arcticus may also struggle to escape predators in the soft, deep snow in Newfoundland's shrub and forest habitat where L. americanus is more successful (Mercer et al. 1981). The more abundant prey species, L. americanus, may have caused a "high density of randomly foraging [shared] predators that 'spill over' into other habitats and decrease the abundance and distribution of alternative prey," in this case, L. arcticus (Small and Keith 1992, p. 1620). Red Foxes have expanded their range in Alaska and other northern regions (Killengreen et al. 2007; Post et al. 2009), moving north of the Brooks Range in the 20th century but largely keeping to the foothills and river corridors except during occasional periods of abundance on the tundra plain of the North Slope (Savory et al. 2014). Red Foxes did become more common on the North Slope in the late 20th century, especially in association with oil development infrastructure, but L. othus persists in western Alaska in partial sympatry with L. americanus and V. vulpes, so the evidence does not support predator spillover as the cause for the potential disappearance of L. othus from north of the Brooks Range.

Zooarchaeological evidence suggests that L. americanus has replaced L. othus in the Lime Hills Cave region (Fig 3), located in what was formerly tundra/alpine habitat but is now boreal spruce-birch forest (Endacott 2008). Endacott (2008) identified all hare remains from the deepest soil strata (late Wisconsin, 14000 years ago) as L. othus and all hare remains from the top strata ( $\geq 8000$ years ago) as L. americanus. The middle strata (14 000-8000 years ago) contained remains of both species. This pattern has been interpreted as being "clearly the result of reduced tundra/alpine habitat in the area and expansion of shrubs and boreal forest" (Endacott 2008, p. 233), a shift in habitat similar to the present expansion of shrubs and trees into former Arctic tundra (Hinzman et al. 2005), although on vastly different time scales. Archaeological remains identified as L. othus have been reported from interior Alaska (Weber et al. 1981; Dixon 1984), which is now predominantly boreal forest and well outside the current distribution of L. othus. Zooarchaeological and ethnological material could provide a better understanding of the historical distribution of L. othus and how it has changed over time. However, a combination of ancient DNA extracted from Beringian paleontological hare remains, together with orders of magnitude more molecular markers than have been employed in the past, will almost certainly be required for definitive resolution.

\section{Taxonomy and gene flow}

Consideration of the Alaska Hare's distribution requires an understanding of its tortuous taxonomic history and current status. Lepus othus is part of a species complex comprising the subgenus Lepus Linnaeus 1758, which currently includes two other northern hare species: the Arctic Hare (L. arcticus) and the Mountain Hare (L. timidus). As currently circumscribed taxonomically, L. othus is restricted to western Alaska, L. arcticus occurs in Greenland and northern Canada from the Northwest Territories to Newfoundland and Ellesmere Island, and L. timidus ranges from the Chukotsk Peninsula in far eastern Russia to eastern 
Poland, throughout Scandinavia, and in isolated populations in Japan, the British Isles, and the Alps (Angerbjörn and Flux 1995).

Geography and allopatry are the principal grounds upon which L. othus, L. arcticus, and L. timidus have retained their separate species status (Anderson 1974). Morphological (Baker et al. 1983; Dixon et al. 1983) and molecular (Waltari and Cook 2005; Alves et al. 2008; Melo-Ferreira et al. 2012) data have been inconclusive or conflicting, and the taxonomy of northern hares remains in dispute. Ranges of the three species are not thought to overlap and therefore gene flow is not thought to occur (Anderson 1974).

The identification (L. othus or L. timidus) of the northern hare sighted on St. Lawrence Island in winter 2012 is unclear. St. Lawrence is $75 \mathrm{~km}$ from the Chukotsk Peninsula but $190 \mathrm{~km}$ from the nearest Alaskan mainland, suggesting that the hare(s) in question likely originated from Russia. Thus, presumably infrequent but recurrent gene flow between the two species may be facilitated by island stepping stones, especially if their thick pelage is providing sufficient insulation to forgo foraging for up to 15 days, as has been theorized for L. arcticus (Wang et al. 1973). Wolverine (Gulo gulo) and Brown Bear (Ursus arctos) are also observed on St. Lawrence Island occasionally, although there are no sustaining populations of either species on the island (as communicated by residents to J.J.B.). However, as climate change continues to affect sea ice extent in the Arctic (Bernstein et al. 2007), there could be a reduction in potential gene flow between in Eurasia, Alaska, and the islands between the two continents.

Clarifying the distributional limits of L. othus will require resolution of northern hare taxonomy given the potential for gene flow between $L$. timidus from eastern Russia and $L$. othus. When the McIlhenny specimen was collected, it was originally identified as Lepus tschuktschorum Nordquist 1883 (Stone 1900), a junior synonym of L. othus that included northern hares from Eastern Siberia and Alaska. If eastern Siberian hare populations are considered conspecific with L. othus, then "[Lepus] tschuktschorum Nordquist, 1883 has priority over [Lepus] othus Merriam, 1900" (Hoffmann and Smith 2005, p. 202).

It is widely agreed that high-latitude regions have been impacted by climate change in the past century and are likely to be inordinately affected by continuing changes in phenology, vegetation cover, snow cover, and ground icing conditions (Hinzman et al. 2005; Bernstein et al. 2007; Prowse et al. 2009; Jorgenson et al. 2015). These changes could make foraging more difficult for herbivores. Shrub cover in the Alaskan Arctic has increased over the past century and is expected to continue to expand, and treeline encroachment into formerly tree-less areas has been documented in western and northern Alaska (Hinzman et al. 2005; Prowse et al. 2009). Such conditions will likely favor the continued expansion of L. americanus into northern and western Alaska. Tundra-associated mammals such as the Barren Ground Shrew (Sorex ugyunak) and Singing Vole (Microtus miurus) are predicted to undergo range shifts away from western and southern extents of Arctic tundra (Hope et al. 2013; Baltensperger and Huettmann 2015).

Although the historical occurrence and abundance of L. othus on the North Slope remains unclear, a northern shift from its current range is predicted by Leach et al. (2015) and may be critical to its long-term viability. Most of the western North Slope lies within the National Petroleum Reserve - Alaska (NPR-A), federal land set aside for potential oil and gas operations. The US Bureau of Land Management has noted the current presumed absence of $L$. othus in its environmental impact statement for the NPR-A (BLM 2012). However, by the end of the 21st century, this region may be the only large expanse of continuous unforested habitat left in Alaska (Prowse et al. 2009; Hope et al. 2013) and much of the shifted range of L. othus as predicted by Leach et al. (2015) lies within the NPR-A, a prospect that echoes recent calls (reviewed by Hannah 2011) for considering probable future range shifts in conservation and management plans. 


\section{Acknowledgements}

This project was funded by a grant from the Alaska Department of Fish and Game (through United States Fish and Wildlife Service Division of Federal Assistance State Wildlife Grant T-1-6), with additional funding from the University of Alaska Fairbanks Graduate School, the Arctic Institute of North America, the David Burnett Dunn Memorial Award, and the University of Alaska Museum. We are deeply grateful to the following individuals, management agencies, and museums for their field support, specimen observations, specimen loans, and access to collections: C.P. Barger (Alaska Department of Fish and Game), S. Lowe (US Fish and Wildlife Service), J. Lawler (National Park Service), A. Whiting (Native Village of Kotzebue), N.A. Boase and K. Khidas (Canadian Museum of Nature), M. Flannery and J.P. Dumbacher (California Academy of Sciences), J. R. Demboski (Denver Museum of Science and Nature), J. Chupasko and H. Hoekstra (Museum of Vertebrate Zoology, Harvard University), J.L. Dunnum and J.A. Cook (Museum of Southwestern Biology, University of New Mexico), M. Revelez and J.K. Braun (Sam Noble Museum of Natural History, University of Oklahoma), G. Shugart (James R. Slater Museum of Natural History, University of Puget Sound), C.W. Thompson and P. Myers (University of Michigan Museum of Zoology), S. Peurach, N. Woodman, and A.L. Gardner (National Museum of Natural History, Smithsonian Institution), J.E. Bradley and S.E. Santana (Burke Museum, University of Washington), G. Sheffield (Marine Advisory Program, University of Alaska Fairbanks), and I. Ahkvaluk. For advice, assistance, and invaluable discussion, we thank A.M. Gunderson, K.B.P. Hildebrandt, K.M. Everson, J.A. Nations, D.R. Klein, D.E. Watts, D. Tinker, E. Waltari, and B.J. McDaniel. Finally, we thank the more than 70 field biologists, subsistence hunters, trappers, and other collectors not mentioned above - living and deceased whose efforts to collect and archive voucher specimens made this study possible.

\section{References}

Alves, P.C., Melo-Ferreira, J., Freitas, H., and Boursot, P. 2008. The ubiquitous mountain hare mitochondria: multiple introgressive hybridization in hares, genus Lepus. Philos. Trans. R. Soc. 263: 2831-2839. doi: http://dx.doi.org/ 10.1098/rstb.2008.0053.

Anderson, H.L., Jr. 1974. Natural history and systematics of the tundra hare (Lepus othus Merriam) in western Alaska. Master's thesis, University of Alaska Fairbanks.

Anderson, H.L., Jr. 1978. Range of the tundra hare. Murrelet. 59(2): 72-74. doi: http://dx.doi.org/10.2307/3534616.

Angerbjörn, A., and Flux, J.E.C. 1995. Lepus timidus. Mammalian Species. 495: 1-11. doi: http://dx.doi.org/10.2307/ 3504302.

Baker, A.J., Eger, J.L., Peterson, R.L., and Manning, T.H. 1983. Geographic variation and taxonomy of Arctic hares. Acta Zool. Fenn. 174: 45-48

Baltensperger, A.P., and Huettmann, F. 2015. Predicted shifts in small mammal distributions and biodiversity in the altered future environment of Alaska: an open access data and machine learning perspective. PLoS One. 10(7): e0132054, doi: http://dx.doi.org/10.1371/journal.pone.0132054.

Bee, J.W., and Hall, E.R. 1956. Mammals of northern Alaska on the Arctic Slope. Edited by E.R. Hall. University of Kansas Museum of Natural History, Lawrence, Kans.

Bernstein, L., Bosch, P., Canziani, O., Chen, Z., Christ, R., Davidson, O., and Hare, W. 2007. Climate change 2007: synthesis report. Valencia. IPCC, Geneva.

Best, T.L., and Henry, T.H. 1994. Lepus othus. Mammalian Species. 458: 1-5. doi: http://dx.doi.org/10.2307/3504196. Breiman, L. 1996. Bagging predictors. Mach. Learn. 24(2): 123-140. doi: http://dx.doi.org/10.1007/BF00058655.

Buckley, J.L., and Scott, R.F. 1957. Review of mammals of northern Alaska on the Arctic Slope. J. Mammal. 388(3): 426-429.

Burch, E.S., Jr. 1988. War and trade. In Crossroads of continents. Edited By W.W. Fitzhugh and A. Crowell. Smithsonian Institution Press, Washington, DC. pp. 227-240.

BLM. 2012. National Petroleum Reserve - Alaska FINAL Integrated Activity Plan/Environmental Impact Statement. Volume 1. Anchorage, Alaska.

Chapman, A.D., and Wieczorek, J. (Editors). 2006. Guide to best practices for georeferencing. Global Biodiversity Information Facility, Copenhagen.

Cutler, D.R., Edwards, K.H., Jr., Cutler, A., Hess, K.T., Gibson, J., and Lawler, J.J. 2007. Randomforests for classification in ecology. Ecology. 88: 2783-2792. doi: http://dx.doi.org/10.1890/07-0539.1.

Dixon, E.J. 1984. Context and environment in taphonomic analysis: examples from Alaska's Porcupine River caves. Quat. Res. 22: 201-15. doi: http://dx.doi.org/10.1016/0033-5894(84)90040-1. 
Dixon, K.R., Chapman, J.A., Willner, G.R., Wilson, D.E., and Lopez-Forment, W. 1983. The New World jackrabbits and hares (genus Lepus). 2. Numerical taxonomic analysis. Acta Zool. Fenn. 174: 53-56.

Endacott, N.A. 2008. The zooarchaeology of Lime Hills Cave: paleoecological and taphonomic insights. Ph.D dissertation, Washington State University, Pullman.

Erxleben, J.C.P. 1777. Classis I. Mammalia. In Systema regni animalis per classes, ordines, genera, species, varietates, cum synonymia et historia animalium. Weygandianis, Lipsiae.

ESRI, Inc. 'ArcGIS 10.3.1', Redlands. Available from: desktop.arcgis.com [accessed January 1, 2016].

Fedorov, V.D., and Stenseth, N.C. 2002. Multiple glacial refugia in the North American Arctic: inference from phylogeography of the collared lemming (Dicrostonyx groenlandicus). Proc. R. Soc. 269: 2071-2077. doi: http://dx.doi.org/ 10.1098/rspb.2002.2126.

Feldhammer, G.A., Thompson, B.C., and Chapman, J.A. (Editors). 2003. Wild mammals of North America: biology, management, and conservation. 2nd ed. The John Hopkins University Press, Baltimore, Md.

Hall, E.R. 1981. The mammals of North America. 2nd ed. Wiley, New York.

Hall, E.R., and Kelson, K.R. 1959. Mammals of North America. 1st ed. The Ronald Press Company, New York.

Hannah, L. 2011. Climate change, connectivity, and conservation success. Conserv. Biol. 25(6): 1139-1142. doi: http:/ dx.doi.org/10.1111/j.1523-1739.2011.01788.x.

Hinzman, L.D., Bettez, N.D., Bolton, W.R., Chapin, F.S., Dyurgerov, M.B., Fastie, C.L., Griffith, B., Hollister, R.D., Hope, A., Huntington, H.P., Jensen, A.M., Jia, G.J., Jorgenson, T., Kane, D.L., Klein, D.R., Kofinas, G., Lynch, A.H., Lloyd, A.H., McGuire, A.D., Nelson, F.E., Oechel, W.C., Osterkamp, T.E., Racine, C.H., Romanovsky, V.E., Stone, R.S., Stow, D.A., Sturm, M., Tweedie, C.E., Vourlitis, G.L., Walker, M.D., Walker, D.A., Webber, P.J., Welker, J.M., Winker, K.S., and Yoshikawa, K. 2005. Evidence and implications of recent climate change in northern Alaska and other Arctic regions. Clim. Change. 72(3): 251-298. doi: http://dx.doi.org/10.1007/s10584-005-5352-2.

Hoffmann, R.S., and Smith, A.T. 2005. Lepus othus. In Mammal species of the world. Edited By D.E. Wilson and D.M. Reeder. 3rd ed. John Hopkins University Press, Baltimore, Md.

Hope, A.G., Waltari, E., Payer, D.C., Cook, J.A., and Talbot, S.L. 2013. Future distribution of tundra refugia in northern Alaska. Nat. Clim. Change. 3(10): 931-938. doi: http://dx.doi.org/10.1038/nclimate1926.

Howell, A.H. 1936. A revision of the American Arctic hares. J. Mammal. 17(4): 315-337. doi: http://dx.doi.org/10.2307/ 1374399.

Jorgenson, M.T., Marcot, B.G., Swanson, D.K., Jorgenson, J.C., and DeGange, A. 2015. R. Projected changes in diverse ecosystems from climate warming and biophysical drivers in northwest Alaska. Clim. Change. 130(2): 131-144. doi: http://dx.doi.org/10.1007/s10584-014-1302-1.

Killengreen, S.T., Ims, R.A., Nigel, Y.G., Bråthen, K.A., Henden, J., and Schott, T. 2007. Structural characteristics of a low Arctic tundra ecosystem and the retreat of the Arctic fox. Biol. Conserv. 135(4): 459-472. doi: http://dx.doi.org/ 10.1016/j.biocon.2006.10.039.

Klein, D.R. 1995. Tundra or Arctic hares. In Our living resources, a report to the nation on the distribution, abundance, and health of U.S. plants, animals, and ecosystems. Edited By E.T. LaRoe, G.S. Farris, C.E. Puckett, P.D. Doran, and M.J. Mac. U.S. Department of the Interior, National Biological Service, Washington, DC. p. 359.

Leach, K., Kelly, R., Cameron, A., Montgomery, I.W., and Reid, N. 2015. Expertly validated models and phylogenetically-controlled analysis suggests responses to climate change are related to species traits in the order Lagomorpha. PLoS One. 10(4): e0122267, doi: http://dx.doi.org/10.1371/journal.pone.0122267.

Linnaeus, C. 1758. Systema Naturae. 10th ed.

MacDonald, S.O., and Cook, J.A. 2009. Recent mammals of Alaska. University of Alaska Press, Fairbanks.

Manville, R.H., and Young, S.P. 1965. Distribution of Alaskan mammals. Circular 211. U.S. Depatrment of the Interior, Fish and Wildlife Service, Bureau of Sport Fisheries and Wildlife, Washington, DC.

Marcot, B.G., Jorgenson, M.T., Lawler, J.P., Handel, C.M., and DeGange, A.R. 2015. Projected changes in wildlife habitats in Arctic natural areas of northwest Alaska. Clim. Change. 130(2): 145-154. doi: http://dx.doi.org/10.1007/ s10584-015-1354-X.

Melo-Ferreira, J., Boursot, P., Carneiro, M., Esteves, P.J., Farelo, L., and Alves, P.C. 2012. Recurrent introgression of mitochondrial DNA among hares (Lepus spp.) revealed by species-tree inference and coalescent simulations. Syst. Biol. 16(3): 367-381. doi: http://dx.doi.org/10.1093/sysbio/syr114.

Mercer, W.E., Hearn, B.J., and Finlay, C. 1981. Arctic hare populations in insular Newfoundland. In Proceedings of the World Lagomorph Conference, Guleph, Ont., August 12-16, 1979. Edited By K. Myers and C.D. MacInnes. University of Guelph, Guelph, Ont. pp. 450-468.

Merriam, C.H. 1900. Papers from the Harriman Alaska expedition. In Proceedings of the Washington Academy of Sciences. Volume II. Washington Academy of Sciences, Washington, DC. pp. 13-30.

Murdoch, J. 1885. Natural history. In Report of the international polar expedition to Point Barrow, Alaska. House of Representatives 48th Congress, 2nd Session, Washington, DC. pp. 90-200.

Murdoch, J. 1892. Ethnological results of the Point Barrow expedition. In Ninth Annual Report of the Bureau of Ethnology to the Secretary of the Smithsonian Institution 1887-1888, Washington, DC. pp. 19-434. doi: http://dx.doi. org/10.5962/bhl.title.32225.

Murie, O.J. 1959. Fauna of the Aleutian Islands and Alaska Peninsula. U.S. Fish and Wildlife Service, Washington, DC. doi: http://dx.doi.org/10.5962/bhl.title.86971.

Murray, D., and Smith, A.T. 2008a. Lepus othus. The IUCN Red List of Threatened Species 2008: e.T11795A3308465. Available from: http://dx.doi.org/10.2305/IUCN.UK.2008.RLTS.T11795A3308465.en [accessed doi: February .8, 2016].

Murray, D., and Smith, A.T. 2008b. Lepus americanus. The IUCN Red List of Threatened Species 2008: e. T41273A10411354. Available from: http://dx.doi.org/10.2305/IUCN.UK.2008.RLTS.T41273A10411354.en [accessed February 8, 2016]. 
Murray, D., and Smith, A.T. 2008c. Lepus arcticus. The IUCN Red List of Threatened Species 2008: e.T41274A10410937. Available from: http://dx.doi.org/10.2305/IUCN.UK.2008.RLTS.T41274A10410937.en [accessed February 8, 2016].

Nordquist, O. 1883. Anteckningar och studier till Sibiriska Ishafskustens däggdjursfauna. In Vega-expeditionens vetenskapliga iakttagelser. pp. 65-117.

NSIDC 2013. Arctic sea ice news and analysis. National Snow and Ice Data Center. Available from: http://nsidc.org/ arcticseaicenews [accessed August 5, 2014].

Orth, D.J. 1971. Dictionary of Alaska place names. U.S. Department of the Interior Geological Survery, Washington, DC. Porsild, A.E. 1945. Mammals of the Mackenzie Delta. Can. Field Nat. 59(1): 4-22.

Post, E., Forchhammer, M.C., Bret-Harte, M.S., Callaghan, T.V., Christensen, T.R., Elberling, B., Fox, A.D., Gilg, O., Hik, D.S., Høye, T.T., Ims, R.A., Jeppesen, E., Klein, D.R., Madsen, J., McGuire, A.D., Rysgaard, S., Schindler, D.E., Stirling, I., Tamstorf, M.P., Tyler, N.J.C., van der Wal, R., Welker, J., Wookey, P.A., Schmidt, N.M., and Aastrup, P. 2009. Ecological dynamics across the Arctic associated with recent climate change. Science. 325: 1355-1358. doi: http://dx.doi.org/10.1126/science.1173113.

Prowse, T.D., Furgal, C., Wrona, F.J., and Reist, J.D. 2009. Implications of climate change for northern Canada: freshwater, marine, and terrestrial ecosystems. Ambio. 38(5): 282-9. doi: http://dx.doi.org/10.1579/0044-7447-38.5.282.

Pruitt, W.O., Jr. 1966. Ecology of terrestrial mammals. In Environment of the Cape Thompson region, Alaska. Edited By N.J. Wilimovsky and J.N. Wolfe. U.S. Atomic Energy Committsion, Division of Technical Information. pp. 519-564.

Rausch, R.L. 1963. A review of the distribution of Holarctic Recent mammals. In Pacific basin biogeography. Edited By J.L. Gressitt. Bishop Museum Press, Honolulu. pp. 29-43.

Rios, N.E., and Bart, H.L. 2014. GEOLocate [Georeferencing Web Application]. Tulane University Biodiversity Research Institute, Belle Chasse, La. Available from: http://www.museum.tulane.edu/geolocate [accessed January 1, 2016].

Ross. 1819. Voy. Discovery, II 2, App. IV.

Salford Systems, Inc. RandomForests. San Diego, Calif. Available from: www.salford-systems.com [accessed January 1, 2016].

Savory, G.A., Hunter, C.M., Wooller, M.J., and O’Brien, D.M. 2014. Anthropogenic food use and diet overlap between red foxes (Vulpes vulpes) and Arctic foxes (Vulpes lagopus) in Prudhoe Bay, Alaska. Can. J. Zool. 92: 657-663. doi: http://dx.doi.org/10.1139/cjz-2013-0283.

Small, R.J., and Keith, L.B. 1992. An experimental study of red fox predation on Arctic and snowshoe hares. Can. J. Zool. 70(8): ): 1614-1621. doi: http://dx.doi.org/10.1139/z92-222.

Stanford, D.J. 1976. The Walakpa site, Alaska: its place in the Birnirk and Thule cultures. Smithsonian Contributions to Anthropology No. 20.

Stone, W. 1900. Report on the birds and mammals collected by the Mcllhenny Expedition to Pt. Barrow, Alaska. Proc. Acad. Nat. Sci. Philadelphia. 52: 4-49

Tape, K.D., Christie, K., Carroll, G., and O’Donnell, J.A. 2016. Novel wildlife in the Arctic: the influence of changing riparian ecosystems and shrub habitat expansion on snowshoe hares. Global Change Biol. 22(1): 208-219

The Alaska Gap Analysis Project. Alaska Natural Heritage Program. Available from: http:/|aknhp.uaa.alaska.edu/ zoology/akgap/ [accessed April 12, 2015]

Waltari, E., and Cook, J.A. 2005. Hares on ice: phylogeography and historical demographics of Lepus arcticus, L. othus, and L. timidus (Mammalia: Lagomorpha). Mol. Ecol. 14: 3005-3016. doi: http://dx.doi.org/10.1111/j.1365-294X. 2005.02625.x.

Waltari, E., Demboski, J.R., Klein, D.R., and Cook, J.A. 2004. A molecular perspective on the historical biogeography of the northern high latitudes. J. Mammal. 85(4): 591-600. doi: http://dx.doi.org/10.1644/BER-101.

Wang, L.C.H., Jones, D.L., MacArthur, R.A., and Fuller, W.A. 1973. Adaptation to cold: energy metabolism in an atypical lagomorph, the Arctic hare (Lepus arcticus). Can. J. Zool. 51(1): 841-6. doi: http://dx.doi.org/10.1139/z73-125.

Weber, F.R., Hamilton, T.D., Hopkins, D.M., Repenning, C.A., and Haas, H. 1981. Canyon Creek: a late Pleistocene vertebrate locality in interior Alaska. Quat. Res. 16(2): 167-180. doi: http://dx.doi.org/10.1016/0033-5894(81)90043-0.

Wilson, D.E., and Ruff, S. (Editors). 1999. The Smithsonian book of North American mammals. Smithsonian Institution Press, Washington, DC.

Yesner, D.R. 2001. Human dispersal into interior Alaska: antecedent conditions, mode of colonization, and adaptations. Quat. Sci. Rev. 20: 315-327. doi: http://dx.doi.org/10.1016/S0277-3791(00)00114-1. 


\section{Appendix}

Table A1. Names and abbreviations of museums and other collections searched through online databases, contact with curators and collection managers, and (or) personal visits.

\begin{tabular}{|c|c|}
\hline Museum name & $\begin{array}{c}\text { Museum } \\
\text { abbreviation }\end{array}$ \\
\hline Academy of Natural Sciences & ANSP \\
\hline American Museum of Natural History & AMNH \\
\hline Burke Museum of Natural History and Culture, University of Washington & UWBM \\
\hline California Academy of Sciences & CAS \\
\hline Canadian Museum of Nature & CMN \\
\hline Carnegie Museum & $\mathrm{CM}$ \\
\hline Charles R. Connor Museum & CRCM \\
\hline Cornell University Museum of Vertebrates & CUMV \\
\hline Cowan Vertebrate Museum, University of British Columbia & UBC \\
\hline Denver Museum of Nature and Science & DMNS \\
\hline Dickey Collection, University of California, Los Angeles & UCLA \\
\hline Field Museum of Natural History & FMNH \\
\hline Humboldt State University Wildlife Collection & HSUW \\
\hline \multicolumn{2}{|l|}{ Izembek NWR } \\
\hline James R. Slater Museum of Natural History, University of Puget Sound & PSM \\
\hline Los Angeles County Museum & LACM \\
\hline Louisiana State University, Museum of Natural Science & LSUMZ \\
\hline Michigan State University Museum & MSU \\
\hline Monte L. Bean Life Science Museum, Brigham Young University & BYU \\
\hline Museum of Comparative Zoology, Harvard & $\mathrm{MCZ}$ \\
\hline Museum of Southwestern Biology, University of New Mexico & MSB \\
\hline Museum of Texas Tech University & TTU \\
\hline Museum of Vertebrate Zoology, University of California & MVZ \\
\hline New Mexico Museum of Natural History & NMMNH \\
\hline New York State Museum & NYSM \\
\hline Oklahoma Museum of Natural History, University of Oklahoma & OMNH \\
\hline Royal British Columbia Museum & $\mathrm{RBCM}$ \\
\hline Royal Ontario Museum & $\mathrm{ROM}$ \\
\hline Texas Cooperative Wildlife Collection & TCWC \\
\hline United States National Museum of Natural History (Smithsonian) & USNM \\
\hline University of Alaska Museum & UAM \\
\hline University of Alberta Museum of Zoology & UAMAZ \\
\hline University of California Davis & UCD \\
\hline University of Colorado Museum & UCM \\
\hline University of Kansas, Natural History Museum and Biodiversity Center & KU \\
\hline University of Michigan Museum of Zoology & UMMZ \\
\hline University of Wisconsin Zoological Museum & UWZM \\
\hline Utah Museum of Natural History, University of Utah & UMNH \\
\hline Western New Mexico University & WNMU \\
\hline
\end{tabular}

